\title{
Performance and digestive characteristics in dairy cattle maintained under grazing regime and supplemented with linseed
}

\section{Desempenho e características digestivas em bovinos leiteiros mantidos em regime de pastoreio suplementados com linhaça}

\author{
Christopher Junior Tavares Cardoso ${ }^{1 *}$; Ana Caroline Bini de Lima ${ }^{1}$; Ériklis \\ Nogueira²; Marcus Vinicius Morais de Oliveira ${ }^{3}$; Fabiana de Andrade Melo-Sterza ${ }^{3}$
}

\begin{abstract}
Linseed is characterized by the rich unsaturated fatty acids and slow release of oil in the rumen. The objective of the present study was to evaluate the intake, rumen degradability, and digestibility of dairy cattle maintained under grazing regime and supplemented with linseed. Twelve Girolando ( $3 / 4$ Holstein $\times 1 / 4$ Gir) cows with a mean age of $5.2 \pm 1.9$ years and body weight of $583.9 \pm 67.6 \mathrm{~kg}$ were used. The cows were maintained in a rotational grazing system on the mombaça grass (Panicum maximum) and divided into 2 experimental groups. The CONTR $(n=6)$ group received only the base diet (pasture) and the LINS group $(n=6)$ received pasture plus linseed. Initially, a fifteen-day adaptation period was established to stabilize the desired consumption amount. After this period, the animals received $800 \mathrm{~g}$ of linseed for $126 \mathrm{~d}$. The ruminal degradability was evaluated using 2 males with a cannula in the rumen, and they were provided the same experimental diet. The measured dry matter production of pasture did not show differences during the experimental period. The intake of crude protein and ethereal extract was higher, whereas neutral detergent fiber content was lower in the cows supplemented with linseed. However, this did not alter the weight gain and digestibility coefficients, except the digestibility coefficient of the ethereal extract. At the ruminal level, linseed showed low effective and potential degradability with negative effect on grass degradability.
\end{abstract}

Key words: Protected fat. Linolenic. Linum usitatissimum.

\section{Resumo}

\begin{abstract}
A linhaça destaca-se pela composição de ácidos graxos ricos em ácidos insaturados e por apresentar lenta liberação do óleo no rúmen. O presente estudo teve como objetivo avaliar o consumo, a degradabilidade ruminal e a digestibilidade em bovinos leiteiros mantidos em regime de pastoreio e suplementados com linhaça em grão. Foram utilizadas 12 vacas da raça Girolando (3/4 Holandês x 1/4 Gir) com idade media de 5,2 \pm 1.9 anos com peso médio de $583.9 \pm 67.6 \mathrm{~kg}$, mantidas em sistema de pastoreio rotacionado de capim-mombaça (Panicum maximum) e divididas em 2 grupos experimentais. O grupo CONTR ( $\mathrm{n}=6)$ recebeu apenas a dieta base (pastagem) e o grupo LINS ( $\mathrm{n}=6$ ) recebeu suplementação com $800 \mathrm{~g} / \mathrm{animal} /$ dia de linhaça. Inicialmente foi realizado um período de adaptação de quinze dias para estabilização
\end{abstract}

\footnotetext{
1 Discentes, Curso de Mestrado, Programa de Pós-Graduação em Zootecnia, Universidade Estadual de Mato Grosso do Sul, UEMS, Aquidauana, MS, Brasil. E-mail: christopher.zootecnista@gmail.com; carolinebini@hotmail.com

2 Dr., Pesquisador A, Empresa Brasileira de Pesquisa Agropecuária, EMBRAPA Pantanal, Corumbá, MS, Brasil. E-mail: eriklis. nogueira@embrapa.br

3 Profs., Programa de Pós-Graduação em Zootecnia, UEMS, Aquidauana, MS, Brasil. E-mail: marcusvmo@uems.br; fabiana. sterza@uems.br

* Author for correspondence
} 
do consumo desejado. Após esse período os animais receberam 800 gramas de linhaça por 126 dias. A degradabilidade ruminal foi avaliada utilizando-se 2 machos fistulados no rúmen e submetidos a mesma dieta. A produção de matéria seca do capim não apresentou diferenças durante o período experimental. As vacas suplementadas com linhaça consumiram mais proteína bruta e extrato etéreo e tiveram menor consumo de fibra em detergente neutro, porém não foi suficiente para alterar o ganho de peso e os coeficientes de digestibilidade, exceto do extrato etéreo. Em nível ruminal a linhaça apresentou baixa degradabilidade efetiva e potencial, tendo efeito negativo sobre a degradabilidade do capim.

Palavras-chave: Gordura protegida. Linolênico. Linum usitatissimum.

\section{Introduction}

During the last decade, interest in the use of lipids in the diet of ruminants has increased. Diets with high energy density can increase feed efficiency by reducing food intake associated with weight gain and also improve milk quality in cattle (GONZALEZ et al., 2015).

The importance of two families of essential fatty acids, omega 3 (n-3) and omega 6 (n-6) (also known as linolenic and linoleic acids, respectively) in the diet, has been emphasized. They are termed essential fatty acids because they must be obtained from the feed when an organism is unable to produce them at sufficient speed to meet the demand (WATHES et al., 2007).

Supplementation of fat in the diet of bovines has negative effects on the digestion of fiber due to the action of long-chain fatty acids on ruminal microorganisms (OLIVEIRA et al., 2012). One way to avoid the negative effect of fat on ruminal fermentation is to provide it in an artificially protected form or as oleaginous seeds in natura (SILVA et al., 2007). Whole seeds have minimal effect on the consumption and digestibility due to the low degradability and slow release of oil in the ruminal environment (ROSA et al., 2013). This has increased the interest in linseed as it is rich in polyunsaturated fatty acids (PUFS), in particular linolenic acid (BENCHAAR et al., 2012). Furthermore, these fatty acids have low ruminal biohydrogenation (CAVALIERI et al., 2005).

The data on ruminal degradation of oilseeds, in whole or ground form, are scarce. The in situ degradation analysis, which evaluates the kinetic parameters of feed by the disappearance of incubated sample mass, is a simple, accurate, and fast method to determine the nutritive value of a food (ORSKOV et al., 1980). Although the food is not subjected to all the digestive events, such as chewing, rumination, and passage, there is no better way to simulate the ruminal environment for a given feeding regime than the in situ technique, because this technique allows the intimate contact of feed with the ruminal environment (VAN SOEST, 1994).

Further, the study of digestibility is important to quantify the use of food by an animal. Different sources of lipids present different effects on nutrient digestibility. No effect was observed on the dry matter and digestibility of dietary fiber with the supplementation of cotton seed (JORGE et al., 2008). However, it has been observed that soybean oil as a source of lipid negatively influenced the digestibility of fiber (OLIVEIRA et al., 2012). Therefore, in addition to the ethereal extract (EE) level, the source might also influence the digestibility and animal performance.

In this milieu, the present study evaluated the consumption, ruminal degradation, and digestion in dairy cattle maintained under grazing regime and supplemented with linseed.

\section{Material and Methods}

The present study was carried out in the Sector of Dairy Cattle Production, Universidade Estadual de Mato Grosso do Sul (UEMS, Unit of Aquidauana, MS, Brazil) from December 2014 to June 2015. All manipulations involving the animals were carried out according to the Ethical Principles 
in Animal Experimentation approved by the UEMS Committee of Ethic and Animal Use (Protocol no. 012/2014). The chemical-bromatological composition analysis of the pasture, linseed, and feces samples was conducted at the UEMS Animal Nutrition Laboratory.

To evaluate performance (i.e., consumption, weight gain, and digestibility), 12 non-pregnant, non-lactating Girolando ( $3 / 4$ Holstein $\times 1 / 4$ Gir) cows with an average body weight of $583.9 \pm 67.6 \mathrm{~kg}$ and a mean age of $5.2 \pm 1.9$ years were used. The cows were randomly assigned to two homogeneous experimental groups: (1) control group (CONTR, $\mathrm{n}=6$ ) not supplemented with brown linseed and
(2) linseed group (LINS, $\mathrm{n}=6$ ) supplemented with brown linseed.

The animals were maintained in a rotational grazing regime on the mombaça grass (Panicum maximum (Table 1), and received water and mineral supplements ad libitum. All the animals were handled together. To eliminate the effects of environment on the management of animals, the animals were taken to the corral every day. Furthermore, only the animals of LINS group received the experimental diet. The linseed (Tables 1 and 2) was supplied individually to ensure that the animals consumed desired amount without competition.

Table 1. Chemical composition (expressed in dry matter) of potentially ingested grass and brown flax grains.

\begin{tabular}{lcc}
\hline Variables* & Mombaça grass & Linseed \\
\hline Dry Matter -DM (\%) & 29.69 & 92.99 \\
Crude Protein - CP (\%) & 7.47 & 22.00 \\
Ethereal extract - EE (\%) & 1.52 & 27.32 \\
Neutral Detergent Fiber - NDF (\%) & 66.25 & 40.09 \\
Acid Detergent Fiber - ADF (\%) & 31.62 & 20.59 \\
Total Carbohydrates - TC (\%) & 81.36 & 43.66 \\
Non-fibrous Carbohydrates - NFC (\%) & 15.11 & 3.57 \\
Mineral Matter - MM (\%) & 9.66 & 7.03 \\
\hline
\end{tabular}

* Average of the samples collected during the experiment.

Table 2. Composition of fatty acids in linseed.

\begin{tabular}{lc}
\hline Fatty Acids & Average \pm SD \\
\hline C12: 0 - Lauric acid (\%) & $0.12 \pm 0.01$ \\
C14: 0 - Myristic acid (\%) & $0.24 \pm 0.01$ \\
C16: 0 - Palmitic acid (\%) & $6.20 \pm 0.12$ \\
C16: 1 - Palmitoleic acid (\%) & $0.11 \pm 0.01$ \\
C18: 0 - Stearic acid (\%) & $3.21 \pm 0.03$ \\
C18: 1 (trans) - Elaidic acid (\%) & $0.25 \pm 0.02$ \\
C18: 1-Oleic acid (\%) & $16.32 \pm 0.05$ \\
C18: 2 - Linoleic acid (omega 6) (\%) & $15.68 \pm 0.01$ \\
C18: 3n3 - Linolenic acid (omega 3) (\%) & $51.89 \pm 0.14$ \\
C20: 0 - Arachidonic acid (\%) & $0.10 \pm 0.01$
\end{tabular}


continuation

\begin{tabular}{lc} 
C20:1 - Cis-11-eicosenic acid (\%) & $0.16 \pm 0.04$ \\
C22: 0 - Behenic acid (\%) & $0.13 \pm 0.01$ \\
\hline Polyunsaturated fatty acids (\%) & $69.95 \pm 5.68$ \\
Monounsaturated fatty acids (\%) & $16.85 \pm 0.09$ \\
Saturated fatty acids (\%) & $10.00 \pm 0.07$ \\
\hline
\end{tabular}

Initially, a fifteen-day adaptation period was established to stabilize the desired consumption amount. After this period, the animals received $800 \mathrm{~g}$ of linseed for $126 \mathrm{~d}$. Six paddocks of size 1.2 ha were prepared and pastured for 6 consecutive days, remaining during the next $30 \mathrm{~d}$. Regulatory animals were used to control the availability of biomass (1800 kg pasture residue) and maintain the nutritional quality of the forage to ensure that the grass was consumed in a similar way in all the paddocks.

From the entrance and exit of each paddock, grass samples were collected, a square of $4 \mathrm{~m}^{2}$ was randomly selected, and the leaf fractions, stem, and senescent material were separated and weighed. This material was stored in a freezer and the DM content was determined. The forage yield during the experimental period - both the initial availability of grass and residue after grazing — was quantified.

The forage consumed by animals was determined indirectly through indigestible acid detergent fiber (IADF) as an internal marker according to the method described by Craig et al. (1984).

To determine digestibility, grass samples were collected, from the entrance and exit of each paddock, at different periods throughout the experiment by the simulated grazing technique. The collection was performed for a period of $40 \mathrm{~min}$, starting before feeding. The animals were monitored from a distance of less than $2 \mathrm{~m}$ to observe the grazing habit and preference for the structural components of the forage. Thus, in a synchronized manner with the cows, forage was manually harvested. Subsequently, the material was homogenized and a sub-sample of approximately $500 \mathrm{~g}$ was stored for further bromatological evaluation.

The fecal samples were collected directly from the rectal bulb of the cows six times throughout the experiment, each at an interval of $21 \mathrm{~d}$. The samples were stored in a freezer for further analysis of chemical components. On the last day of the experiment, the fecal production of the animals was determined by total fecal collection for a period of 24 h.

At the end of the experiment, samples of grass, linseed, and feces were thawed; oven dried at $65^{\circ} \mathrm{C}$ for $72 \mathrm{~h}$; ground to a size of $2 \mathrm{~mm}$ using a Willey mill; placed in plastic pots; identified; and stored until further analysis. The samples were used to determine the content of dry matter (DM), crude protein $(\mathrm{CP})$, ethereal extract (EE), mineral matter (MM), neutral detergent fiber (NDF), and acid detergent fiber (ADF) according to the methodology proposed by the Association of Official Analytical Chemists (AOAC, 1990). Hemicellulose (HEM) content was determined by the difference between the NDF and ADF of the analyzed material. The total carbohydrate (TC) content was obtained using the equation: $100-(\mathrm{CP}+\mathrm{EE}+\mathrm{MM})$; and non-fibrous carbohydrates (NFC) by the difference between TC and NDF.

The ruminal degradability of the potentially ingested grass (samples collected from the simulated grazing area of the Girolando cows) and brown linseeds was verified by the in situ technique using two castrated adult males weighing an average of $650 \mathrm{~kg}$ with a permanent cannula in the rumen (Protocol n 008/2013). 
The oxen were maintained with the Girolando cows throughout the experimental period, and were also used as pasture regulating animals. Thus, along with the performance analysis, ruminal degradation was determined by incubating the samples of grass potentially ingested by the Girolando cows in TNT bags measuring $14 \mathrm{~cm} \times 7 \mathrm{~cm}$ with $50-\mu \mathrm{m}$ pores containing about $5 \mathrm{~g}$ of previously dried and ground samples. These bags were then placed in mesh bags measuring $15 \mathrm{~cm} \times 30 \mathrm{~cm}$ with a small lead weight of $100 \mathrm{~g}$ and were tied to a line of free length approximately $0.5 \mathrm{~m}$.

The bags were introduced directly into the rumen for $96,72,48,24,12,8,6,4$, and $2 \mathrm{~h}$, respectively. At $0 \mathrm{~h}$, the bags containing the feed were preincubated in a vessel with water. The TNT bags were removed simultaneously and washed under running water. The residues obtained after incubation were dried in a forced ventilation oven at $65^{\circ} \mathrm{C}$ for $48 \mathrm{~h}$ and stored until further analysis. The samples were used to determine the contents of DM, CP, NDF, ADF, and EE.

Subsequently, the oxen were supplemented with $800 \mathrm{~g}$ of brown linseed every day. After $5 \mathrm{~d}$ of ruminal adaptation, a new set of feed samples potentially ingested by the Girolando cows (grass and linseed) were incubated to observe the possible effect of supplementation on the degradability of the samples.

The data on the disappearance of DM, CP, $\mathrm{NDF}, \mathrm{ADF}$, and EE were calculated based on the difference in weight before and after incubation. To estimate the parameters, the first-order asymptotic model proposed by Orskov and McDonald (1979) was used: $P D=a+b\left(1^{\mathrm{e}}-\mathrm{ct}\right)$; where, PD is the potential rumen degradation of feed; $a$ is the soluble fraction; $b$ is the potentially degradable fraction of the insoluble fraction that will be degraded at the rate ' $c$ '; $c$ is the degradation rate of fraction ' $b$ '; and $\mathrm{t}$ is the incubation period in $\mathrm{h}$.

The fraction considered non-degradable (I) was calculated using the equation: $I=(100-(a+b))$. To estimate effective degradability (ED), the following mathematical model was used: $E D=a+[(b \times c) /$ $(\mathrm{c}+\mathrm{K})]$; where, $\mathrm{K}$ is the rate of passage of solids through the rumen (defined as $2 \%, 5 \%$, and $8 \%$ per $\mathrm{h}$, which can be attributed to the low, medium, and high levels of food intake).

Blood samples were collected six times from all the animals to quantify glucose, albumin, and cholesterol throughout the period of supplementation. The blood samples were collected by puncturing the caudal vein and deposited in test tubes. After collection, the sample was centrifuged at $3000 \mathrm{rpm}$ for $10 \mathrm{~min}$ for serum separation and the serum obtained was stored at $-20^{\circ} \mathrm{C}$ until further analysis.

Total cholesterol (colorimetric enzymatic method), albumin (bromocresol colorimetric enzyme-green method), and glucose (enzymehexokinase method with commercial kits using the COBAS ${ }^{\circledR}$ automated spectrophotometer (RocheHitachi, Indianapolis - IN, USA.) contents were quantified in the serum. The blood metabolites were analyzed at the Clinical Veterinary Pathology Laboratory of the Federal University, Mato Grosso do Sul.

The lipid profile of linseed was performed according to the methodology of Nunes et al. (2015) by gas chromatography (Agilent 6890N, Ramsey $\mathrm{MN}$, USA) to obtain individual peaks of fatty acid methyl esters. The analysis was carried out in the Nutrition Laboratory, Universidade Católica Dom Bosco.

The Girolando cows were weighed every 21 d (accounting to 6 measurements throughout the experiment) to monitor the average daily gain. The cows were always weighed in the morning before the supplementation of linseed.

The environmental condition was monitored throughout the experimental period through the readings recorded at the Meteorological Station, Universidade Estadual de Mato Grosso do Sul, Aquidauana Unit. 
Figure 1 shows the mean temperature and were $26^{\circ} \mathrm{C}$ and $79.93 \%$, respectively; no significant relative humidity recorded during the experimental changes were observed. period. The mean temperature and relative humidity

Figure 1. Mean temperature and relative humidity during the experimental period.

\section{Index of temperature and relative humidity}

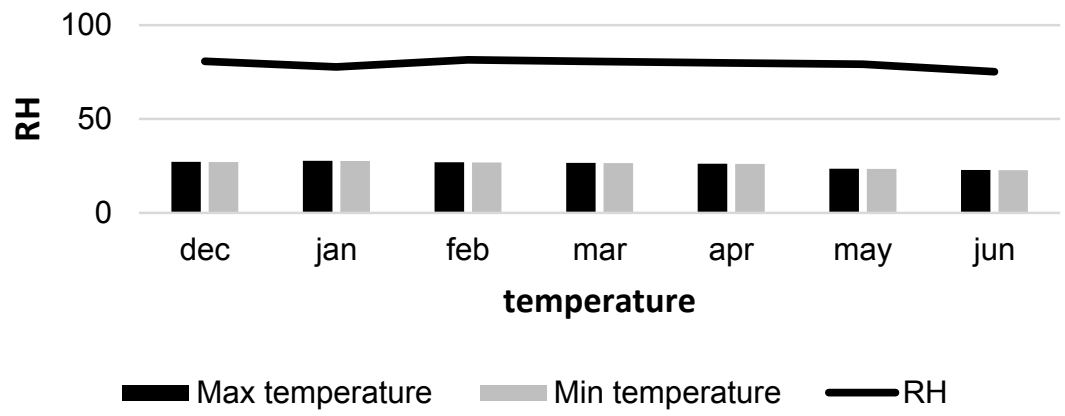

The experimental design was completely randomized with two treatments. For each variable studied, the normality of variance distribution was verified by the Shapiro-Wilk test with a probability value $(\mathrm{P})$ of 0.05 as significant. The data was transformed if necessary. The variables - feed intake, digestibility, and weight gai - were statistically analyzed using the R software. The data were subjected to analysis of variance (ANOVA), and a significant difference $(\mathrm{P} \leq 0.05)$ between the means was determined.

\section{Results and Discussion}

In the present study, the average forage yield was $1,856.1 \mathrm{~kg}$ of DM per ha (or $7,138.8 \mathrm{~kg}$ of green matter per ha) with leaves, stem, and senescent material representing 45.7\%, 44.0\%, and $10.3 \%$, respectively. There was no difference in the forage yield during the experimental period. When evaluating the performance of calves in the pasture of mombaça grass, Moreira et al. (2008) reported that the leaves represented $38 \%$ of forage yield, which is lower than the value obtained in the present study. Lima et al. (2007) reported that leaves represented $55.5 \%$ of forage yield during the rotational management of lactating cows. This value is close to that observed in the present study where grazing was in a rotational system. The differences in pasture quality observed in these studies might be due to animal category, physiological status, psychogenic effects, and environmental condition.

The chemical composition of linseed and pasture potentially ingested by the animals are presented in Table 1. The results revealed the adequate nutritional quality of the mombaça grass with an average crude protein content of $7.5 \%$. The linseed presented higher amount of protein and ethereal extract, which is characteristic of a proteic-energetic feed.

The average EE content of linseed was $27.3 \%$. Further, the fatty acid composition of linseed was consistent with that reported by the American Oil Chemists' Society (AOCS) (FIRESTONE, 2006). The linseed oil consists of $51 \%$ omega-3, $15.6 \%$ omega- $6,16 \%$ monounsaturated fatty acids, and only $10 \%$ saturated fatty acids. The concentration of omega-3 fatty acid is three-times higher than that of omega- 6 fatty acid, making it the largest plant source of linolenic acid (RAMCHARITAR et al., 2005). 
In the present study, linseed supplementation did not alter $(\mathrm{P}>0.05)$ the consumption of mombaça grass and intake of total $\mathrm{DM}, \mathrm{ADF}, \mathrm{TC}, \mathrm{NFC}$, and MM. Higher protein (22\%) and NDF (40.09) contents were observed in the linseed. This might be due to the fibro-protein matrix of linseed shell. These results are similar to the findings (CP, 23.09\%; NDF, 48\%) of Wada et al. (2008).

In the present study, there was a decrease in the intake of NDF by the cows in LINS group ( $\mathrm{P}=$ $0.0352)$. However, there was a significant increase in the intake of $\mathrm{CP}(\mathrm{P}=0.0048)$ and $\mathrm{EE}(\mathrm{P}<0.0001)$ due to high content of protein and fatty acids in the linseed (Table 2).

In the present study, the DM intake of ADF, TC, NFC, and MM was not significantly influenced by the experimental diet (Table 3). However, there was a decrease $(\mathrm{P}<0.05)$ in the intake of NDF and an increase in the intake of EE and CP. The intake of linseed improved the total diet (pasture and linseed) - the classic substitutive effect. The animals substituted a part of the pasture with the linseed to improve the diet ingested, thus increasing the amount of energy and protein.

Table 3. Daily intake (expressed as dry matter) of cows supplemented with linseed.

\begin{tabular}{llll}
\hline Variables & Control & Linseed & P Value \\
\hline Mombaça grass - kg & 12.67 & 12.15 & 0.2046 \\
Total DM (grass + linseed) - kg & 12.67 & 12.92 & 0.5452 \\
Body Weight (BW) - \% & 2.13 & 2.14 & 0.9665 \\
Metabolic Weight - g/kg BW ${ }^{0.75}$ & 105.29 & 106.13 & 0.7988 \\
Crude Protein - kg & 1.01 & 1.09 & 0.0048 \\
Neutral Detergent Fiber - Kg & 9.06 & 8.56 & 0.0352 \\
Acid Detergent Fiber - Kg & 4.40 & 4.16 & 0.1073 \\
Ethereal extract - kg & 0.20 & 0.40 & $<0.0001$ \\
Total Carbohydrates - Kg & 11.11 & 11.08 & 0.9328 \\
Non-fibrous Carbohydrates - Kg & 2.02 & 1.94 & 0.1317 \\
Mineral Matter - kg & 0.31 & 0.30 & 0.8591 \\
\hline
\end{tabular}

Sousa et al. (2008) evaluated the consumption of dairy cows under grazing regime with different amounts of concentrate. The results revealed that the increase in intake of the total diet was due to partial substitution of grass with the concentrate, that is, the increase in concentrate consumption decreased the consumption of pasture. Silva et al. (2009) observed a decline in pasture consumption among cows, which highlighted the direct influence of pasture DM consumption on concentrate levels $(0,1,3$, and $5 \mathrm{~kg} / \mathrm{d})$.

In the present study, the amount of linseed supplied $(800 \mathrm{~g})$ was relatively low in comparison with that of these studies. Therefore, the amount of supplement might not have been sufficient to statistically alter the consumption of grass by the animals. Further, the results demonstrate the nutritional balance between the experimental groups indicating that the amount of grass was sufficient to meet the nutritional demand of the animals.

The in situ evaluation revealed that the linseed presented a low fermentation rate for all analyzed variables (DM, CP, NDF, ADF, and EE) with a disappearance rate of not more than $57 \%$ in 96 $\mathrm{h}$, except the protein level that reached $73 \%$. This demonstrates that a large part of the shell, 
endosperm, and seed oil passed through the ruminal environment, and were available to be digested in the small intestine (Table 4). However, it was observed that the percent of disappearance of DM, CP, NDF, and $\mathrm{ADF}$ of the mombaça grass was higher at all the incubation times in the animals fed only the pasture when compared with those of the animals fed the pasture plus linseed diet. This indicates the negative effect of linseed on the fermentation of grass.

Table 4. Percent of mean ruminal disappearance of dry matter (DM), crude protein (CP), neutral detergent fiber (NDF), acid detergent fiber (ADF), and ethereal extract (EE) of the mombaça grass at different incubation times.

\begin{tabular}{|c|c|c|c|c|c|c|c|c|c|c|c|}
\hline \multirow{2}{*}{ Diet } & & \multicolumn{10}{|c|}{ Incubation Time (hours) } \\
\hline & & $\mathbf{0}$ & 2 & 4 & 6 & 8 & 12 & 24 & 48 & 72 & 96 \\
\hline \multirow{5}{*}{ Grass } & \multicolumn{11}{|c|}{ Mombaça grass } \\
\hline & $\mathrm{DM}$ & 6,6 & 26,4 & 30.9 & 34.5 & 37.1 & 45.4 & 55.2 & 66.8 & 72.5 & 76.1 \\
\hline & $\mathrm{CP}$ & 20.1 & 43.9 & 51.9 & 58.4 & 61.7 & 67.9 & 75.2 & 85.6 & 87.8 & 90.5 \\
\hline & NDF & 6.6 & 12.7 & 15.5 & 17.6 & 22.9 & 29.5 & 39.4 & 56.9 & 66.4 & 70.5 \\
\hline & $\mathrm{ADF}$ & 11.4 & 36.4 & 45.6 & 46.4 & 52.5 & 52.9 & 60.9 & 69.2 & 77.1 & 80.5 \\
\hline \multirow{11}{*}{$\begin{array}{l}\text { Grass } \\
+ \\
\text { Linseed }\end{array}$} & \multicolumn{11}{|c|}{ Linseed } \\
\hline & $\mathrm{DM}$ & 0.7 & 9.9 & 14.3 & 15.1 & 16.5 & 18.5 & 23.1 & 34.7 & 45.7 & 54.8 \\
\hline & $\mathrm{CP}$ & 1.4 & 18.6 & 21.6 & 29.8 & 32.7 & 38.3 & 42.7 & 53.4 & 66.1 & 73.0 \\
\hline & NDF & 1.3 & 4.5 & 9.8 & 12.2 & 21.9 & 23.1 & 23.8 & 33.4 & 46.6 & 50.4 \\
\hline & $\mathrm{ADF}$ & 0.8 & 5.2 & 11.9 & 17.0 & 21.1 & 22.8 & 24.8 & 30.3 & 38.3 & 41.9 \\
\hline & $\mathrm{EE}$ & 0.7 & 9.9 & 14.3 & 15.1 & 16.5 & 18.5 & 23.1 & 34.7 & 45.7 & 54.8 \\
\hline & \multicolumn{11}{|c|}{ Mombaça grass } \\
\hline & $\mathrm{DM}$ & 5.7 & 27.2 & 29.2 & 31.1 & 35.1 & 36.8 & 40.5 & 52.4 & 62.8 & 70.2 \\
\hline & $\mathrm{CP}$ & 14.9 & 45.9 & 50.6 & 53.3 & 56.5 & 59.6 & 63.8 & 72.9 & 77.5 & 77.7 \\
\hline & NDF & 5.8 & 7.5 & 11.1 & 15.2 & 19.9 & 23.3 & 27.6 & 40.3 & 51.2 & 62.0 \\
\hline & $\mathrm{ADF}$ & 8.1 & 30.4 & 44.1 & 47.4 & 49.7 & 51.2 & 51.6 & 60.1 & 66.3 & 73.7 \\
\hline
\end{tabular}

The linseed exhibited a low potential rate of fraction ' $b$ ' of DM was $69.56 \%$ (Table 5). degradability (PD) of DM (Table 5). Goes et al. This difference might be due to the method in which (2011) incubated crushed linseed and reported that the potentially degradable fraction ' $b$ ' of linseed was $87.89 \%$. In the present study, the degradation the linseeds were incubated, as crushing linseed increases the exposure and access of nutrients to the microorganisms. 
Table 5. Degradability coefficients 'a', 'b', 'c', and 'I' of the dry matter and its effective degradability (ED) with $2 \%$, $5 \%$, and $8 \%$ per h pass rates of the mombaça grass and linseed according to the diet ingested.

\begin{tabular}{|c|c|c|c|c|c|c|c|c|}
\hline \multirow{2}{*}{ Diet } & \multirow[b]{2}{*}{ Variables } & \multicolumn{4}{|c|}{ Coefficients* } & \multicolumn{3}{|c|}{$\operatorname{ED}(\% / \mathrm{h})$} \\
\hline & & $\mathrm{a}(\%)$ & $\mathrm{b}(\%)$ & c $(\% / h)$ & $\mathrm{I}(\%)$ & 2 & 5 & 8 \\
\hline \multirow{5}{*}{ Grass } & & \multicolumn{7}{|c|}{ Mombaça grass } \\
\hline & $\mathrm{DM}$ & 15.23 & 57.99 & 0.0559 & 26.78 & 57.9 & 45.8 & 39.1 \\
\hline & $\mathrm{CP}$ & 25.83 & 60.03 & 0.1185 & 14.14 & 77.2 & 68.1 & 61.7 \\
\hline & NDF & 8.20 & 66.44 & 0.0284 & 25.36 & 47.2 & 32.2 & 25.6 \\
\hline & \multirow[t]{2}{*}{$\mathrm{ADF}$} & 22.14 & 51.14 & 0.1060 & 26.72 & 65.2 & 56.9 & 49.8 \\
\hline \multirow{11}{*}{$\begin{array}{c}\text { Grass } \\
+ \\
\text { Linseed }\end{array}$} & & \multicolumn{7}{|c|}{ Linseeds } \\
\hline & $\mathrm{DM}$ & 8.11 & 69.56 & 0.0111 & 22.33 & 32.9 & 20.7 & 16.6 \\
\hline & $\mathrm{CP}$ & 11.11 & 56.73 & 0.0449 & 32.16 & 50.4 & 38.0 & 31.5 \\
\hline & NDF & 5.28 & 47.3 & 0.0259 & 47.42 & 31.9 & 21.4 & 16.8 \\
\hline & $\mathrm{ADF}$ & 3.15 & 34.02 & 0.0654 & 62.83 & 29.2 & 22.4 & 18.5 \\
\hline & $\mathrm{EE}$ & 6.88 & 41.85 & 0.0431 & 51.27 & 35.5 & 26.3 & 21.5 \\
\hline & & \multicolumn{7}{|c|}{ Mombaça grass } \\
\hline & $\mathrm{DM}$ & 15.14 & 43.51 & 0.0636 & 41.35 & 48.2 & 39.5 & 34.4 \\
\hline & $\mathrm{CP}$ & 26.57 & 46.47 & 0.1416 & 26.96 & 67.3 & 60.9 & 56.3 \\
\hline & NDF & 8.35 & 69.27 & 0.0143 & 22.38 & 37.2 & 23.7 & 18.8 \\
\hline & $\mathrm{ADF}$ & 11.43 & 49.81 & 0.2916 & 38.76 & 58.0 & 54.0 & 50.5 \\
\hline
\end{tabular}

* a: soluble fraction; b: potentially degradable fraction; c: fraction degradation rate b. from "a": soluble fraction degraded at time zero, "b": potential degradability in function of time, "c": fractional fraction degradation rate "b" per unit of time, and "I" undegradable fraction.

Similar to the findings of Goes et al. (2011), linseed presented a low percent of potentially degradable fraction and soluble fraction of CP in the present study. In addition, the linseed presented a high undegradable fraction. Numerous alternatives have been evaluated to decrease the degradability of protein in the rumen, and thereby allowing better availability of amino acids for intestinal digestion. In general, the whole grains present a low soluble fraction of $\mathrm{CP}$, which lowers the degradability. To the best of our knowledge, no information regarding ruminal degradation of $\mathrm{NDF}, \mathrm{ADF}$, and $\mathrm{EE}$ of linseed are available. In the present study, a low ED was observed for these variables.

Lower PD (Tables 4 and 5) and ED were observed for all the variables when the animals were fed linseed. The decrease in fiber degradability was due to the effect of linseed oil on grass particles. According to Nagaraja et al. (1997), unsaturated fatty acids are generally toxic to Gram-positive bacteria. The mechanism might involve a change in cell membrane permeability, which reduces the ability of cell to regulate intracellular $\mathrm{pH}$ and nutrient uptake. Oleic, linoleic, and linolenic fatty acids significantly inhibit the growth of cellulolytic bacteria, such as Butyrivibrio fibrisolvens, Ruminococcus albus, and $R$. flavefaciens, thus reducing the degradability of fiber.

A low soluble fraction of DM, CP, NDF, ADF, and $\mathrm{EE}$ in linseed has been reported. In the present study, the linseed presented a degradation rate of the potentially degradable fraction and undegradable fraction of $42 \%$ and $51 \%$, respectively, for EE. This indicates the low PD and ED of linseeds (Table 5). 
In relation to the mombaça grass, the soluble fraction of the variables, DM, CP, NDF, and ADF, in both the diets (pasture and pasture plus linseed) was similar, except for ADF. However, a reduction in the potentially degradable fraction of the DM and $\mathrm{CP}$ in grass was observed in the diet pasture plus linseed when compared with those of the control diet (pasture only). Consequently, there was an increase in the non-degradable fraction of these variables. It has also been reported that in pasturefed animals, the ED of mombaça grass was higher for all variables analyzed at the pass rate of $2 \%, 5 \%$, and $8 \%$ per $h$.

The digestibility coefficient of DM, CP, ADF, TC, NFC, MM, and total digestible nutrients did not show significant differences $(\mathrm{P}>0.05)$ between the groups (Table 6). However, in LINS group, a higher EE digestibility coefficient $(\mathrm{P}<0.0001)$ was observed when compared with that of the CONTR group. In contrast, the digestibility coefficient of
NDF tended to be lower in LINS group $(\mathrm{P}=0.0579)$.

Generally, the study of digestibility is important to quantify the use of feed by an animal. However, in the present study, the linseed did not significantly influence $(\mathrm{P}>0.05)$ the $\mathrm{DM}, \mathrm{CP}, \mathrm{TC}, \mathrm{NFC}, \mathrm{ADF}$, $\mathrm{MM}$, and total digestible nutrients.

The digestibility coefficient of EE was higher in the LINS group due to higher amount of lipids from linseed ingested by the animals. This might be because the linseed is coated by a fibro-proteic matrix, which results in the slow release of lipids in the ruminal environment. This allows the ruminal microorganisms to hydrogenate the double bonds of unsaturated fatty acids, thus preventing the inhibitory effect of lipid on fiber digestibility (COPPOCK; WILKS, 1991). Furthermore, if the amount is not sufficient to adhere to the food particle, it causes physical impediment to microbes and microbial enzymes (VALINOTE et al., 2005).

Table 6. Digestibility coefficient (expressed in DM) of control (only pasture) and linseed diets (pasture plus linseed) of the Girolando cows maintained under grazing regime.

\begin{tabular}{lccc}
\hline Variables & Control & Linseed & P Value \\
\hline Dry Matter - \% & 62.88 & 63.11 & 0.8394 \\
Crude Protein - \% & 55.26 & 62.70 & 0.2541 \\
Neutral Detergent Fiber - \% & 77.15 & 75.36 & 0.0579 \\
Acid Detergent Fiber - \% & 74.77 & 72.45 & 0.1194 \\
Total Carbohydrates - \% & 70.47 & 69.91 & 0.4854 \\
Non-fibrous Carbohydrates - \% & 40.25 & 37.0 & 0.4447 \\
Ethereal extract - \% & 40.70 & 69.31 & $<0.0001$ \\
Mineral Matter - \% & 31.41 & 30.92 & 0.8591 \\
Total Digestible Nutrients - \% & 62.89 & 63.83 & 0.2179 \\
Digestible Energy - kcal/gMS & & 2.81 & 0.2179 \\
\hline
\end{tabular}

${ }^{1}$ DE: $(\% \mathrm{TDN} / 100) * 4,409$, according to NRC (2001).

In the present study, the NDF digestibility coefficient tended to be lower $(\mathrm{P}=0.0579)$ in the LINS group. Wada et al. (2008) reported lower DM digestibility coefficient in cows treated with linseed. Although no statistical difference in the digestibility of fiber was observed, they attributed the lower DM digestibility coefficient to the lipids in linseed that might have inhibited cellulolytic microorganisms.

There is a reduction in the digestibility of fiber when lipid sources are added to the feed. The magnitude of reduction is related not only to the 
quantity, but also to the type of fatty acid present in the supplement. Lipids rich in unsaturated fatty acids tend to decrease digestibility (SMITH et al., 2006), which corroborates with the lower digestibility coefficient in the cows supplemented with linseed observed in the present study.
The effect of diets on the serum concentration of metabolites is presented in Table 7. The supplementation of lipid did not affect $(\mathrm{P}>0.05)$ the concentration of serum glucose, albumin, and cholesterol. The values were within the normal limits (glucose, 45.00 to $75.00 \mathrm{mg} / \mathrm{dL}$; albumin, 3.3 to $3.55 \mathrm{~g} / \mathrm{dL}$; and cholesterol, 80 and $120 \mathrm{mg} / \mathrm{dL}$ ).

Table 7. Serum concentration of metabolites in the Girolando cows maintained under grazing regime on the mombaça grass with or without linseed supplementation.

\begin{tabular}{lccc}
\hline Variables & Control & Linseed & P Value \\
\hline Glucose - mg/dL & 59.4 & 59.2 & 0.8274 \\
Albumin - g/dL & 3.61 & 3.5 & 0.5642 \\
Cholesterol - mg/dL & 104.1 & 116.3 & 0.7453 \\
\hline
\end{tabular}

These results corroborate with those of the other studies that provided diets enriched with PUFAs to bovine females (NOGUEIRA et al., 2012). Due to the glucose-lowering mechanism of ruminants, the effect of treatments on serum glucose concentration was not expected, which explains the maintenance of glycemia (GAGLIOSTRO; CHILLIARD, 1991).

In the present study, there was no difference in the total serum albumin concentration between the groups $(\mathrm{P}>0.05)$. The evaluation of serum albumin helps determine the intake of protein from feed (NOGUEIRA et al., 2012). Although CP consumption was higher $(\mathrm{P}<0.05)$ in LINS group when compared with that of the CONTR, it was not sufficient to alter the serum albumin concentration, which remained within the normal standard set for cows (ECKERSALL, 2008).

The administration of fat to bovine females stimulates the synthesis and accumulation of cholesterol in tissues and body fluids. Studies have reported that increasing fat in the diet increases the cholesterol levels (NOGUEIRA et al., 2012). In the present study, no difference was observed in the concentration of serum cholesterol between the groups.

In the present study, no significant difference ( $\mathrm{P}$ $>0.05$ ) was observed between daily average weight gains. This indicates that linseed supplementation had no influence on tissue deposition. The average weight and daily gain are presented in Table 8 .

Table 8. Initial and final body weights, and daily weight gain in Girolando cows maintained under grazing regime on the mombaça grass with or without linseed supplementation.

\begin{tabular}{lcc}
\hline Variables* & Control & Linseed \\
\hline Inicial Body Weight - kg & 583.3 & 584.5 \\
Final Body Weight - kg & 613.1 & 618.5 \\
Daily Average Weight Gain - kg & 0.236 & 0.270 \\
\hline
\end{tabular}

The weight gain was relatively low with an average of $250 \mathrm{~g} / \mathrm{d}$. However, this was consistent with the diet offered and category evaluated, that is, adult cows with stabilized body weight. 


\section{Conclusions}

Linseed has low ED and PD, which decreases the degradability and digestibility of grass. However, it does not alter the concentration of serum metabolites, weight gain, and digestibility coefficients, except the EE digestibility coefficient, which was high when the female Girolandos consumed $800 \mathrm{~g}$ of linseed every day.

\section{Acknowledgment}

To UEMS, to FUNDECT and CNPq for the support and financial support given in this experiment and to UFMS and UCDB for carrying out the analyzes.

\section{References}

ASSOCIATION OF OFFICIAL ANALYTICAL CHEMISTS - AOAC. Official methods of analysis. $15^{\text {th }}$ ed. Washington: AOAC, 1990.

BENCHAAR, C.; ROMERO-PÉREZ, G. A.; CHOUINARD, P. Y.; HASSANAT, F.; EUGENE, M.; PETIT, H. V.; CÔRTES, C. Supplementation of increasing amounts of linseed oil to dairy cows fed total mixed rations: effects on digestion, ruminal fermentation characteristics, protozoal populations, and milk fatty acid composition. Journal of Dairy Science, Lancaster, v. 95, n. 8, p. 4578-4590, 2012.

CAVALIERI, F. B.; SANTOS, G. T.; MATSUSHITA, M.; PETIT, H. V.; RIGOLON, L. P.; SILVA, D. Milk production and milk composition of dairy cows fed Lac100® or whole flaxseed. Journal of Animal Science, Lancaster, v. 85, n. 3, p. 413-416, 2005.

COPPOCK, C. E.; WILKS, D. L. Supplemental fat in high-energy rations for lactating cows: effects on intake, digestion, milk yield, and composition. Journal of Animal Science, Lancaster, v. 69, n. 9, p. 3826-3827, 1991.

CRAIG, W. M.; HONG, B. J.; BRODERICK, G. A.; BULA, R. J. In vitro inoculum enriched with particleassociated microorganisms for determining rates of fiber digestion and protein degradation. Journal of Dairy Science, Lancaster, v. 67, n. 12, p. 2902-2909, 1984.

ECKERSALL, P. D. Proteins, proteomics, and the dysproteinemias. In: KANEKO, J. J.; HARVEY, J. W.; BRUSS, M. L. (Ed.). Clinical biochemistry of domestic animals. $6^{\text {th }}$ ed. San Diego: Academic Press, 2008. p.
117-155.

FIRESTONE, D. AOCS catalog, physical and chemical characteristics of oils, fats, and waxes. $2^{\text {th }}$ ed. Boulder: AOCS Press, 2006. 237 p.

GAGLIOSTRO, G.; CHILLIARD, Y. Duodenal rapeseed oil infusion in early and midlactation cows. In vivo and in vitro adipose tissue lipolytic responses. Journal of Dairy Science, Lancaster, v. 74, n. 6, p. 1830-1843, 1991.

GOES, R. H. T. B.; SOUZA, K. A.; NOGUEIRA, K. A. G.; PEREIRA, D. F.; OLIVEIRA, E. R.; BRABES, K. C. S. Degradabilidade ruminal da matéria seca e proteína bruta, e tempo de colonização microbiana de oleaginosas, utilizadas na alimentação de ovinos. Acta Scientiarum. Animal Sciences, Maringá, v. 33, n. 4, p. 373-378, 2011.

GONZALEZ, F.; MUIÑO, R.; PEREIRA, V.; MARTINEZ, D.; CASTILLO, C.; HERNÁNDEZ, J.; BENEDITO, J. L. Milk yield and reproductive performance of dairy heifers and cows supplemented with polyunsaturated fatty acids. Pesquisa Agropecuária Brasileira, Brasília, v. 50, n. 4, p. 306-312, abr. 2015.

JORGE, J. R. V.; ZEOULA, L. M.; PRADO, I. N.; SILVA, R. R.; ANDRADE, R. V.; PRADO, J. M.; BUBLITZ, E. E. Lipídios em dietas para novilhos holandeses: digestibilidade aparente. Revista Brasileira de Saúde Produção Animal, Salvador, v. 9, n. 4, p. 743-753, 2008.

LIMA, M. L. P.; LEME, P. R.; PINHEIRO, M. G.; BERCHIELLI, T. T.; NOGUEIRA, J. R. Vacas leiteiras mantidas em rotacionado de capim elefante guaçu e capim tanzânia: produção e composição do leite. Pesquisa e Tecnologia, Campinas, v. 4, n. 1, p. 67-75, 2007.

MOREIRA, F. B.; MIZUBUTI, I. Y.; PRADO, I. N.; MATSUSHIATA, M.; MATSUBARA, M. T.; DOGANI, R. Suplementação com sal mineral proteinado para bezerros mantidos em pastagem de capim Mombaça, no inverno. Semina: Ciências Agrárias, Londrina, v. 29, n. 1, p. 203-210, 2008.

NAGARAJA, T. G.; NEWBOLD, C. J.; van NEVEL, C. J.; DEMEYER, D. I. Manipulation of ruminal fermentation. In: HOBSON, P. N.; STEWART, C. S. (Ed.). The rumen microbial ecosystem. Springer: Dordrecht, 1997. p. 523632.

NOGUEIRA, É.; SILVA, A. S. D.; AMARAL, T. B.; ÍTAVO, L. C. V.; DIAS, A. M.; MINGOTI, G. Z. Follicular dynamics and production of oocytes in young Nellore heifers with energetic supplementation. Revista Brasileira de Zootecnia, Viçosa, MG, v. 41, n. 9, p. 20122017, 2012.

NATIONAL RESEARCH COUNCIL - NRC. Nutrient requirements of dairy cattle. $7^{\text {th }}$ ed. Washington, DC: Academic Press, 2001.381 p. 
NUNES, A. A.; FAVARO, S. P.; GALVANI, F.; MIRANDA, C. H. B. Good practices of harvest and processing provide high quality Macauba pulp oil. European Journal of Lipid Science and Technology, Weinheim, v. 117, n. 12, p. 2036-2043, 2015.

OLIVEIRA, E. A.; SAMPAIO, A. A. M.; HENRIQUE, W.; PIVARO, T. M.; ROSA, B. L.; FERNANDES, A. R. M.; ANDRADE, A. T. Quality traits and lipid composition of meat from Nellore young bulls fed with different oils either protected or unprotected from rumen degradation. Meat Science, Cowra, v. 90, n. 1, p. 28-35, jan. 2012.

ORSKOV, E. R.; HOVELL, F. D. D.; MOULD, F. The use of the nylon technique for the evaluation of feedstuffs. Tropical Animal Production, Edinburgh, v. 5, n. 3, p. 195-213, 1980.

ORSKOV, E. R.; McDONALD, I. The estimation of protein degradability in the rumen from incubation measurements weighted according to rate of passage. Journal of Agriculture Science, Loughborough, v. 92, n. 1, p. 499-508, 1979.

RAMCHARITAR, A.; BADRIE, N.; MATTFELDTBEMAN, M.; MATSUO, H.; RIDLEY, C. Consumer acceptability with Muffind flaxseed (linum usitatissimum). Journal offood Science, Medford, v. 70, n. 7, p. 504-507, 2005.

ROSA, B. L.; SAMPAIO, A. A. M.; HENRIQUE, W.; OLIVEIRA, E. A.; PIVARO, T. M.; ANDRADE, A. T.; FERNANDES, A. R. M. Performance and carcass characteristics of Nellore young bulls fed different sources of oils, protected or not from rumen degradation. Revista Brasileira de Zootecnia, Viçosa, MG, v. 42, n. 2, p. 109-116, 2013.

SILVA, C. V. D.; LANA, R. D. P.; CAMPOS, J. M. D. S.; QUEIROZ, A. C. D.; LEÃO, M. I.; ABREU, D. C. D. Consumo, digestibilidade aparente dos nutrientes e desempenho de vacas leiteiras em pastejo com dietas com diversos níveis de concentrado e proteína bruta. Revista Brasileira de Zootecnia, Viçosa, MG, v. 38, n. 7, p. 1372-1380, out. 2009.
SILVA, M. M. C.; RODRIGUES, M. T.; RODRIGUES, C. A. F.; BRANCO, R. H.; LEÃO, M. I.; MAGALHÃES, A. C. M.; MATOS, R. S. Efeito da suplementação de lipídios sobre a digestibilidade e os parâmetros da fermentação ruminal em cabras leiteiras. Revista Brasileira de Zootecnia, Viçosa, MG, v. 36, n. 1, p. 246256, fev. 2007.

SMITH, S. B.; LUNT, D. K.; CHUNG, K. Y.; CHOI, C. B.; TUME, R. K.; ZEMBAYASHI, M. Adiposity, fatty acid composition, and delta-9 desaturase activity during growth in beef cattle. Animal Science Journal, Medford, v. 77, n. 5, p. 478-486, 2006.

SOUSA, B. M.; SATURNINO, H. M.; BORGES, A. L. C. C.; LOPES, F. C. F.; SILVA, R. R.; CAMPOS, M. M.; PIMENTA, M.; CAMPOS, W. E. Estimativa de consumo de matéria seca e de fibra em detergente neutro por vacas leiteiras sob pastejo, suplementadas com diferentes quantidades de alimento concentrado. Arquivo Brasileiro de Medicina Veterinária e Zootecnia, Belo Horizonte, v. 60, n. 4, p. 890-895, ago. 2008.

VALINOTE, A. C.; NOGUEIRA FILHO, J. C. M.; LEME, P. R.; SILVA, S. D. L. E.; CUNHA, J. A. Fontes de lipídeos e monensina na alimentação de novilhos Nelore e sua relação com a população de protozoários ciliados do rúmen. Revista Brasileira de Zootecnia, Viçosa, MG, v. 34, n. 4, p. 1418-1423, 2005.

VAN SOEST, P. J. Nutritional ecology of the ruminant. $2^{\text {th }}$ ed. New York: Cornell University Press, 1994. 476 p.

WADA, F. Y.; PRADO, I. N.; SILVA, R. R.; MOLETTA, J. L.; VISENTAINER, J. V.; ZEOULA, L. M. Grãos de linhaça e de canola sobre o desempenho, digestibilidade aparente e características de carcaça de novilhas Nelore terminadas em confinamento. Ciência Animal Brasileira, Goiânia, v. 9, n. 4, p. 883-895, 2008.

WATHES, D. C.; ROBERT, D.; ABAYASEKARA, E.; AITKEN, R. J. Polyunsaturated fatty acids in male and female reproduction. Biology of Reproduction, New York, v. 77, n. 2, p. 190-201, ago. 2007. 
